\title{
屋久島における滞在型エコツーリズム
}

一地域住民との連携を主軸とした確立可能性一

*深見 聡 . $* *$ 坂田 裕輔 . $* * *$ 柴崎 茂光

キーワード：屋久島, 世界自然遺産, 地域資産, 地域通貨, 農業体験

\section{The Staying-longer Style of Eco-tourism in Yaku-Island}

- The Establishment Possibility which Set the Principal Axis

as Cooperation with a Local Resident-

*FUKAMI, Satoshi **SAKATA, Yusuke

***SHIBASAKI, Shigemitsu

Keywords : Yaku- Island, World Natural Heritage site, Regional Resources, LETS System, Agriculture Experience

\section{Summary :}

The number of tourists coming to the Yaku Islands had increased rapidly since 1993 when it was designated as World Natural Heritage site. Most tourists are interested only in its natural resources while it has rich cultural resources and attractive people.

In this paper, the potential of a new tourism style which enphasis on staying longer and the experiences in Yaku-Island have been observed. In Yaku Island, the field research is held in Haruo area which is the south east side of the island.

The Haruo area is proved to have plenty of regional resources that can provide various experiences such as farm staying and envrionmental studies.

To encourage Eco-tourism in Haruo area, the potential of using LETS system (Local Exchange and Transfer System) are examined. It has shown that some new trades between local people and tourists such as teaching local culture and local foods would stimulate local economies.

*鹿児島大学大学院人文社会科学研究科博士後期課程

*Graduate Student, Doctoral Program in Humanities and Social Sciences, Kagoshima University.

$* *$ 鹿児島大学法文学部助教授

**Faculty of Law, Economics and Humanities, Kagoshima University.

***東京大学大学院農学生命科学研究科助手

***Graduate School of Agricultural and Life Sciences, University of Tokyo. 


\section{I ．はじめに}

日本における島嶼部の大半は, 過疎化の進展 により, 地域社会を支えてきた社会的, 経済的 基盤が失われ，社会生活を支える諸種の機能は， 質的，規模的にも縮小しつつある。

こうした島嶼がおかれている状況にあって， 屋久島は注目すべき例外的な場所となっている (図 1 )。世界自然遺産への登録により，一種の ブランドを確立して以来, 観光をおもな目的と した来島者は, 持続的な増加傾向で推移してい るからである。

しかし, 観光客の増加によって経済的な利益 を享受している者は，大規模な観光資本やエコ ッアーガイドといった専門家, つまりは, 島外 からやってきた人々が中心である。彼らが活躍 する限定的なルートから離れた地域に生活する 屋久島の多くの住民には, 観光業発展にともな う経済的効果はほとんどおよんでいない。

これまで，屋久島とともに生きてきたと自負 する住民たちは, 今日のところ, 屋久島観光の 発展という社会的な変化から取り残されている。 他方, 来島者も, わざわざ足を運んだ屋久島で, 企業型の観光のみに身を任せていたのでは, 期

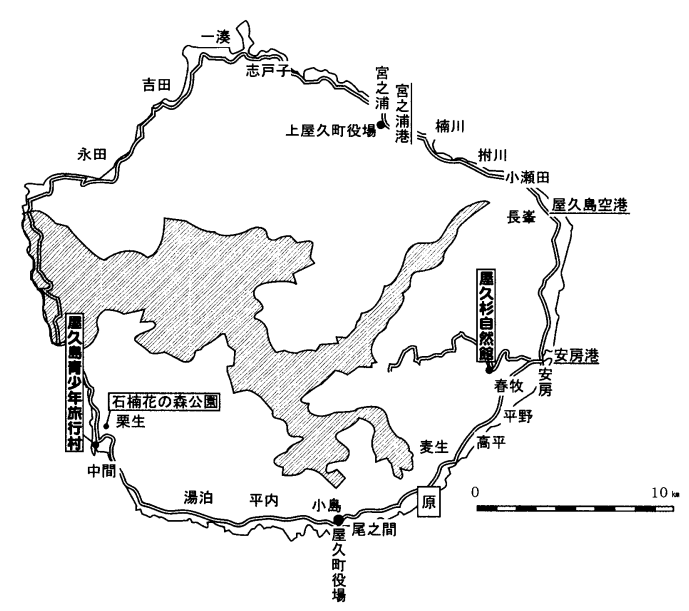

図1. 屋久島の概観

注 : 斜線部分は世界自然遺産指定地域。
待した感動を味わうには充分とはいえない。

実は, 従前の観光ルートと離れた地域社会に は，自然と深く結びついた生業，伝統に支えら れた文化が存在している。それらにふれること が，今日の観光客が望んでいる「いやし」と大 きく重なる。こうした空間の一端を体験する観 光が，いわゆるエコツーリズムである。

観光先進地といわれるヨーロッパでは, 早期 にエコリーリズム，グリーンツーリズムの概念 を定着させてきた。近年，日本においても，エ コッーリズムの充実を求める声は強くなってい るものの，いまだに，屋久島のような地域単位 で大々的に展開されている事例は少ない。エコ ッーリズムは, 地域住民と観光客の双方に意識 の切り替えを求めるし，その成立には，いくつ かの仕掛けや工夫が必要であることが，両者の 立場においてほとんど理解されていないためで ある。

本稿は, 対象地を決定し, エコッーリズムを 展開するのに必要な諸条件を, 実践的視点から 考察し，エコッーリズムの確立に寄与すること を目的としておこなった。

\section{II. 屋久島観光の概観と本研究の視角}

はじめに, 屋久島観光の発展と地域住民との 関係についてふれておきたい。

2003年は，1993年12月に屋久島が世界自然遺 産に登録されてから10年という節目にあたる。 「洋上アルプス」と称される屋久島の自然環境は,

1) 屋久島全体の約 $20 \%\left(107 \mathrm{~km}^{2}\right)$ にあたる地域が指 定を受けた (範囲分布は図 1 参照)。その招もな理 由は、(1)日本の固有植物であるスギの森林が優れ た生態系のもとに成立していること、(2)温帯から 亜寒帯の気候区をもつことから、東アジアにある 植物の多くが生息していること、(3)照葉樹林が広 範囲にかつ原生状態で残っていることの 3 点に集 約できる (村上，2000)。 
一躍，世界からの注目を集めた。鹿児島県は, これに先駆けて1992年に『屋久島環境文化村マ スタープラン』を策定し，保存と活用，すなわ ち屋久島がすでに有する自然価值を，環境教育 的側面から新たな観光資本として整備していく 方針を打ち出した。とくにこの間，I ターンに よる定住者が増加したことを主な要因として， 過疎傾向にあった屋久島の人口は転入者が転出 者を上回るようになった。おなじく熊毛郡に属 する種子島と対照的に，わずかずつながら増加 傾向に転じ，現在もその傾向は続いている また，観光を目的とした来島者は，鹿児島県全 体への入り込み客数が近年は減少を続けている にもかかわらず，屋久島は例外的ともいえる増 加が認められる ${ }^{3}$ 。このような観光需要の増加 に応えるために, 宿泊施設の集積, 景勝観光地

(千人)

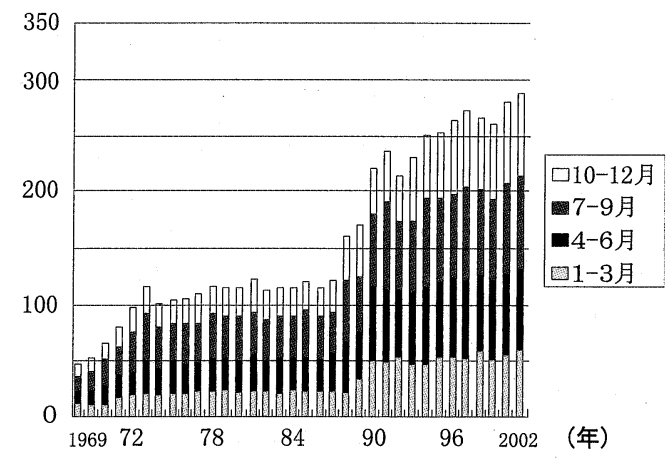

図 2 屋久島への入り込み客数の推移(1969年～2002年) 注:種子屋久観光連絡協議会資料より作成。

2) 田島 (2001) によれば、屋久島へのI ターン移住 者の増加は世界自然遺産登録以降に顕著になって いる。

3) 1989年に、ジェットホイル (高速船) が就航した ことで、鹿児島市との交通利便性が向上したこと も大きな要因といえよう。

4) とくに、Iターン移住者を中心とした「エコッアー ガイド」や民宿経営者数の増加、駐車場やトイレ 施設の整備が顕著である。このような動向は、屋 久島に限ったことではなく、自然景観がいわゆる 「観光地化」していく過程でみられることである。 山村 (1995) に詳しい。
での駐車場等整備も急速にすすんだ4。図 2 は, 屋久島への入り込み客数 ${ }^{5}$, 高度経済成長期 から経年別にしめしたものである。これをみる と，屋久島への入り込み客数は，1990年までは， 多少の増減はありながら，最高でも 10 万人台前 半で推移している。ところが，1990年を境に, 急激な増加状態を呈し，ここ数年は，20万人台 後半に達するまでになった。さらに表 1 は，そ の増加傾向のみられる1990年代後半の, 屋久島 への入り込み客数および観光客数を, 表 2 は, 屋久島の主要な観光施設の利用者数の推移を年

\begin{tabular}{|c|c|c|c|c|c|c|c|}
\hline & \multicolumn{3}{|c|}{ 入り込み客数 (人) } & \multicolumn{3}{|c|}{ 観 光 客 数 (人) } & \multirow[b]{2}{*}{ 対前年比(\%) } \\
\hline & 航 路 & 空路 & 計 & 航路 & 空路 & 計 & \\
\hline 1996年 & 195,880 & 56,958 & 252,838 & 117,310 & 33,036 & 150,346 & $(+10.8)$ \\
\hline 1997年 & 202,821 & 61,013 & 263,734 & 121,460 & 35,388 . & 156,848 & $(+4.3)$ \\
\hline 1998年 & 211,288 & 68,447 & 279,735 & 127,683 & 39,699 & 167,382 & $(+6.7)$ \\
\hline 1999年 & 193,927 & 66,234 & 260,161 & 115,081 & 38,422 & 153,503 & $(-8.3)$ \\
\hline 2000年 & 191,570 & 71,507 & 263,077 & 113,778 & 41,483 & 155,261 & $(+1.1)$ \\
\hline
\end{tabular}
資料:『平成 13 年度版統計やく』(鹿児島県屋久町編)より作成。 (a) 屋久杉自然館

\section{表2. 屋久島の主要観光施設の利用者数}

\begin{tabular}{r|r|c}
\multicolumn{1}{c}{ 年, } & 人館者数(人) & 対前年比(\%) \\
\hline 1989 & 11,868 & - \\
90 & 24,877 & $(+109.6)$ \\
91 & 25,049 & $(+0.7)$ \\
92 & 31,889 & $(+27.3)$ \\
93 & 31,646 & $(-0.8)$ \\
94 & 37,557 & $(+18.7)$ \\
95 & 40,227 & $(+7.1)$ \\
96 & 46,603 & $(+15.9)$ \\
97 & 38,682 & $(-17.0)$ \\
98 & 43,660 & $(+12.9)$ \\
99 & 42,253 & $(-3.2)$ \\
2000 & 40,688 & $(-3.8)$ \\
\hline
\end{tabular}

資料:『平成 13 年度版統計やく』(鹿児島県屋久町編)より作成。 注:1989年10月開館。

(b) 石楠花の森公園

\begin{tabular}{r|r|c}
\hline \multicolumn{1}{c|}{ 年 } & 入園者数(人) & 対前年比 $(\%)$ \\
\hline 1995 & 7,361 & - \\
96 & 3,362 & $(-54.4)$ \\
97 & 3,029 & $(-10.0)$ \\
98 & 2,222 & $(-26.7)$ \\
99 & 2,348 & $(+5.7)$ \\
2000 & 2,648 & $(+12.8)$ \\
\hline
\end{tabular}

資料:『平成 13 年度版統計やく』(鹿児島県屋久町編)より作成。

(c) 屋久島青少年旅行村

\begin{tabular}{r|r|c}
\hline \multicolumn{1}{c|}{ 年 } & 利用者数(人) & 詨前年比 $(\%)$ \\
\hline 1997 & 7,648 & - \\
98 & 8,371 & $(+9.5)$ \\
99 & 7,115 & $(-15.1)$ \\
2000 & 6,505 & $(-8.6)$ \\
-01 & 6,385 & $(-1.8)$ \\
\hline
\end{tabular}

資料:『平成 13 年度版統計やく』(鹿児島県屋久町編)より作成。

5) 観光目的以外の者もふくむ。 
別にまとめたものである。すると，屋久島への 来島者, とりわけそのなかでも観光客数は, 毎 年ほほ増加の傾向であるのに対し，主要観光施 設の利用者数は, 入り込み客数の推移とは, 必 ずしも比例しているとは限らない。たとえば, 屋久杉自然館 ${ }^{6}$ は，縄文杉や白谷雲水峡に代表 される自然環境を，写真パネルや模型で体系的 に紹介することで，環境教育に寄与することを 目的に設置された博物館相当施設である。しか し，本館の利用者数に注目してみると，世界自 然遺産登録以後，とくに1994～96年は着実な増 加傾向にあったものの, その後は 4 万人台前半 へと漸隇してきている。また，石楠花の森公 園 $^{7}$, 屋久島青少年旅行村 ${ }^{8}$ の利用者数も伸び悩 みの状況となっている。このことは，屋久島を 訪れる観光客が，いわゆる「箱モノ」や人工的 に整備された施設に魅かれて滞在しているので はなく，自然体験，あるいはそれに類似した， 「屋久島を体感できる」9 空間を求めてきている ことがうかがえる。

しかし，これら屋久島のおもな観光ポイント として挙げられているものの多くは, 世界自然 遺産指定地域内のものである。つまり，人々が

6) 屋久町安房に建てられた町営有料施設。縄文杉、 江戸時代の屋久杉利用や、戦前の伐採道具など、

屋久杉に関することを総合的に解説している。

7) 屋久町栗生に建てられた町営有料 ( 9 〜翌 2 月は 無料) 施設。固有種である、屋久島高配種のシャ クナゲを中心に，110種を植栽している。

8) 屋久町栗生に建てられた町営有料 ( $4 \sim 10$ 月営 業) のキャンプ施設。

9)このような発言は、ヒアリングをおこなった観光 客にほぼ共通して見出せる傾向として位置づける ことができる。湯本貴和氏 (屋久島 F W 講座代表) は、『第11回環境自治体会議屋久島会議会議資料 集』のなかで、このような期待に応える構想とし て、1980年代後半から、「屋久島オープン・フィー ルド博物館」が発案されていたことを紹介してい る。これは、日本における、エコ・ミュージアム 的構想の先駆け的事例といえる。
暮らしている集落を主たる対象地ととらえる観 光の確立について，世界自然遺産地域と同様に 注目されてきたとはいえない。とくに，世界自 然遺産登録以後，「手付かずに残る自然」が注 目され，観光客が急増した一方で，地域住民に は複雑な胸中が交錯している ${ }^{10}$ 。「いっそのこと, 指定されなければよかった」という声があるの も事実であり (坂田, 2003a), 今後屋久島の観 光を考えていくうえで，地域住民の心情も充分 に考慮していく必要がある。

また，観光客に対する特性については，柴崎・ 永田 (2000) が，来島者に実施したアンケート に分析をくわえ，その傾向を明らかにしている。 そのなかで, 全国平均とくらべて, 旅行費用へ の支出が小さい九州地方からの来島者で屋久島 観光客の約半数は占められている。このことか ら, 自然環境保護に有効な費用負担導入 (環境 キップ制度などによる徵収金) を仮に実施する には，より慎重な対応が必要であることを示唆 した。また，屋久島観光の望ましい形態として， 「観光客が自然としての屋久杉に感動するのも, 人間の手が加わったところで生まれた切株更新 や土埋木の不可思議さによるところが大きいの ではないだろうか。という視点から，屋久島 観光は自然と人間の行為が密接に絡み合ってい るところに魅力があることを指摘する者も多い (吉田,2003)。しかし，これまでの研究では，自 然と人間のかかわりについては, 若干の言及が なされてはいるものの，現実には，そのような 自然環境と人間環境の営みにふれるような事業 が活発に展開されているとはいえない。屋久島

10)筆者らによるヒアリングによれば、観光客増加 が必ずしも島民の所得増加につながっていないと いう生活実態を抱いたり、観光客の増加によって、 「手つかず」の自然が破壊されているという不満を もつ住民も少なくない、という。 
が背負う「世界自然遺産」という看板によって, 観光客に対しては, 地域の文化・歴史などの人 間環境"に視点をむけた観光資源に注目が向き にくくなっている可能性も，充分に考えなけれ ばならない。地域には，自然環境のみならず， 共生する人間環境がある。屋久島もその例にも れない。つまり，人間環境のなかにも，観光資 源となりうる何らかの魅力が存在しているはず である。

また, 観光に求められる多様性については, 国内ではとくに1990年代以降，「持続可能」と いう言葉が登場してから注目されるようになっ た。バブル崩壊後の経済不況が回復の兆しをみ せないなか, 観光においても,「ソフト」や 「エコ」といった，脱大型リゾートを意識した 語句が多用されている。このような動向の背景 には，不況によって高額な旅行を回避し，国内 で安価な観光への転化が進んだという経済的要 因以外にも，冒頭で述べた「いやし」の効果を 求める心身医療的側面 ${ }^{12}$, 観光地に対して「学 び」あるいは「体験」という要素をより重視す る, 生涯学習的側面からの需要などが複合的に 作用している点を考慮する必要がある。

そこで, 次章以降では, エコッーリズムの定 着を検討するうえで, 必要な要素を多く備えて いる屋久島を事例として, 地域住民にとっても 有意なエコツーリズムの成立要件について考察 していく。さらには, それを地域振興事業とし て確立させるために必要な, いくつかの仕掛け や整備手法を具体的に提案する。こうした成果 を積み重ねることは，これまでの議論には久け

11) 本稿でいう「人間環境」とは、現在、屋久島にあ る生活集落およびその近辺地域のことをさす。

12) 屋久島におけるアイランドテラピーについては、 村上 (2000) に詳しい。
ていたエコッーリズムの実践的な課題の全体像 を提起することにつながると考えられるからで ある。

\section{III. エコツーリズムの定義と屋久島の観光イメージ}

\section{1. 日本におけるエコッーリズムの定義}

はじめに, 本稿で取り上げるエコッーリズム とは一体どのようなものなのか, その定義から 整理する。エコツーリズムについては, 概念論 から実際の観光地における実践論にいたるまで, 観光に関する諸研究のなかで, 近年もっとも活 発な議論が展開されている。2002年は「国際ツー リズム年」ということもあり, 観光の果たす役 割として，とくにエコッーリズムに求められる ものは何かを議論するシンポジウム ${ }^{13}$ が国内各 地で開催された。それとともに, エコッーリズ ムは，急速に注目を集める代表的な観光形態と して，次第に認識されるようになった。しかし ながら，両者の間に定義の一致はみられず,

「日本における『エコッーリズム』とは何か」 という回答は, 多種多様に提示されているのが 現状である。

日本におけるエコツーリズムの概念の萌芽期 は，自然破壊がすすんだといわれる高度経済成 長期以後といわれ，各地で散在的に発現した。 全国的な関心喚起の契機となったのは，1989年 に小笠原ホエール・ウォッチング協会が発足し たことが知られる (中井, 2002)。翌年, 環境 庁はエコッーリズムを国立公園活用策の一環に

13) たとえば、地理科学学会は、2002年春季シンポジ ウム「エコッーリズムを考える一自然保護と地域 経済の両立をめぐる諸問題一」を開催した。欧州・ 白神山地 - 小笠原・宮島などの事例から日本にお けるエコツーリズムの果たす役割等について、活 発な議論がなされた。 
すえたことから，さらに注目度が高まった (翁 長，2000)。また，山田 (2002) は，開発途上国 を例に挙げ，エコッーリズムとは「地球に残さ れた数少ない原生自然と, 先住民の生活文化を 対象にした，新しいッーリズムであり，利益よ りも保全を主たる目的としている」と定義した。 山田の定義は,「先住民」を「地域住民」と置 きかえれば，日本におけるエコッーリズムの概 念として用いえよう。さらに， I U C N ${ }^{14}$ の定 義では，エコツーリズムが成功するためには, 自然環境とそれを保護する各機関，それに関係 する地域コミュニティ，自然環境を楽しむため のサービスを提供する観光産業の三者協力の不 可欠さを強調している (フンク,2002)。しかし, 観光については，一般的に経済活動の対象とし て,さまざまな思惑がからみやすい。それゆえ に,このような概念論と実際の活動との間に混 沌とした状態が生じているといえる。エコッー リズムのとらえ方が，いまだ一般化されるまで には至っていない。

以上の問題をふまえて, 宮内 (2003) は, 26 編の先行研究から, エコッーリズムの定義分類 をおこなっている。定義する立場としては， 「自然環境保護関係者」「観光事業関係者」「地 域振興企画者」「研究者」に大別でき，各定義 を内容別に(1)環境保全，(2)環境教育，(3)地域振 興，(4)資金還元，(5)社会現象の五つに整理した。 また，これまでの定義数の多さに着目し，その

\footnotetext{
14) International Union for Conservation of Nature and Natural Resourcesの略称。日本名は国際自然保護 連合といい、1948年に設立された。各国・地域の 行政機関が参加しているN G Oで、世界遺産条約 により、遺産の選出等の役割を与えられている民 間非営利団体である。IUCN日本委員会は、IUCN に加盟する国内団体の連絡組織として1980年に設 立されている。
}

定義を「経済波及効果や雇用効果は, あくまで も二次的なもの, あるいは環境保全や環境教育 をより円滑に行なうための潤滑油」であって， 「それらを主たる目的にすべきではない」と集 約した。また，対象地については，「自然環境 のみ」，あるいは「人間が作り出した文化など， 人文・社会環境まで広く対象地に含める」二つ の立場がある。以上の分類から，宮内 (2003) は,「定義の違いが, 実際にエコッーリズムに よる観光形態を地域に導入した後, それがエコ ツーリズムであるとか，ないとかの真贋論争」 に発展する要因になっていると結論づけた。し かし，いずれの定義にも一貫して読み取れるの は, エコッーリズムとは, 環境教育的要素をふ くんだ観光という特徽である。このことから， 環境教育の領域には，環境保全にかかわる自然 環境，人間環境いずれの地域も包含して対象と することが一般的といえる。

つまり，日本におけるエコッーリズムの概念 は，一見，十人十色なものと判断されがちであ るが，共通の目的は見出せた。本稿では，「環 境教育的側面を不可欠な要素として組み込んだ, 地域文化観光の一形態」と定義する。そのうえ で, 屋久島のエコッーリズムの動向をみていこ う。

\section{2. 屋久島におけるエコッーリズムの展開}

1990年代初頭, 日本でも「エコッーリズム」 という言葉が聞かれるようになった。そのなか でも屋久島は, 1990年に, 国内での推進地区の 一つに選定されるなど，1993年の世界自然遺産 指定にむけた布石となる国による評価がなされ ている。同時に, 少人数で来島する者も増加し ていたものの，何度も屋久島を訪れるうちに， エコッアーガイドだけでは飽き足らず，地域住 
民との交流を目的とする傾向がみられるように なった (中田， 2003)。世界自然遺産指定後の 屋久島は，まさに日本のエコッーリズムの実験 場的な諸活動がみられるようになり，とくに， 観光客が関心を抱きやすい森林や滝などをめぐ るエコッアーが人気をよんだ。表 3 にもあるよ うに，ガイド業は，1998年以後の増加傾向から， 屋久島観光において成長している職業分野と位 置づけられる。しかし，エコッーリズムの定義 でふれたように，人間環境と一体になった観光 プランは, 増加の傾向にはなく, むしろ皆無と いってよい15。屋久島におけるこれまでのエコ
ツーリズムの動向要因として，フンク (2002) がしめした三者協力のうち，「地域コミュニティ」 の担う役割が, 観光客の需要動向の把握や組織 としての需要体制が未成熟のままであることが 推察できる ${ }^{16}$ 。

このような傾向は，全国の観光地でみられつ つある現象である。観光の選択肢の多様化を図 る期待が，「節目の10年」の経過した屋久島に おいても同様に高まっていると考えられる。人々 が観光に出かける背景には，多くの理由が考え られるが，概して，みずからが居住する地域を 離れた場所に対する「いやし」や「学び」への

表3. 屋久島内外のエコツーリズムの展開

\begin{tabular}{|c|c|c|}
\hline 年 & 屋久島の動き & 国内の動き \\
\hline 1989 & & ・「小笠原ホエール・ウオッチング協会」発足 \\
\hline 1990 & $\begin{array}{l}\text { •「国内エコツーリズム推進方策 } \\
\text { 検討調査」で、国内 } 5 \text { 所のうう } \\
\text { ちの1か所に選ばれる。 }\end{array}$ & $\begin{array}{l}\text { •環境庁エコツーリズムを提唱(『熱帯地域 } \\
\text { 生態系保全に関する取組について』報告 } \\
\text { 書) }\end{array}$ \\
\hline 1992 & & $\begin{array}{l}\text { •日本環境教育フォーラム清里ミーティング } \\
\text { '92で、エコツーリズムの概念について議論 }\end{array}$ \\
\hline 1993 & $\begin{array}{l}\text { •屋久島、世界自然遺産指定。 } \\
\text { •屋久島野外活動総合セン } \\
\text { タ一設立。 }\end{array}$ & $\begin{array}{l}\text { ·JATA((社) 日本旅行業協会)、「地球にや } \\
\text { さしい旅人宣言」発表 }\end{array}$ \\
\hline 1994 & $\begin{array}{l}\text { •屋久島フォーラム'94 in } \\
\text { TOKYOで「屋久島エコミュージ } \\
\text { アム構想」。 }\end{array}$ & $\begin{array}{l}\text { ・日本自然保護協会「エコツーリズム・ガイド } \\
\text { ライン」発表。 } \\
\text { •「OSAKA観光宣言」(世界観光大臣会議)。 }\end{array}$ \\
\hline 1995 & & $\begin{array}{l}\text { ·JATA、エコツーリズムセミナー開催。 } \\
\text { ·運輸省、国内観光促進協議会エコツーリ } \\
\text { ズムワーキング・グループを設置。 }\end{array}$ \\
\hline 1996 & & $\begin{array}{l}\text { •IUCN、第2回東アジア国立公園保護地域 } \\
\text { 会議開催。 } \\
\text { •「西表島エコツーリズム協会」発足。 }\end{array}$ \\
\hline 1997 & & •『エコツーリズム研究会レポート集』発行。 \\
\hline 1998 & ・ガイド業が急増し始める。 & $\begin{array}{l}\text { •『JATAエコツーリズムハンドブック』出版。 } \\
\text { •日本エコツーリズム推進協議会設立。 } \\
\text { •「北海道エコツーリズム推進協議会準備 } \\
\text { 会」発足。 }\end{array}$ \\
\hline 1999 & & $\begin{array}{l}\text { •『エコツーリズムの世紀』(エコツーリズム推 } \\
\text { 進協議会)出版。 }\end{array}$ \\
\hline 2002 & & •「国際エコツーリズム年」(国連)。 \\
\hline
\end{tabular}

注:宮内(2003)および大山(2003)をもとに作成。

15) 大手旅行業者の屋久島ツアーや、屋久島在住者に よる観光案内パンフレットにしめされているプラ ンの大半は、人間環境を対象としたものではなく、 もっぱら「世界自然遺産」登録地となっている自 然環境を主に置いたものが目立つ。
16)筆者らによるヒアリングによれば、地域住民のう ち屋久島観光の伸展と、地域住民の生活の二つが、 おなじ島内で営まれているにもかかわらず、ほと んど接点のないまま展開されている、と感じてい る者が大半をしめている。 
欲求ととらえることができる。屋久島への来島 者も同様に, とくにリピーター客の場合, 多様 な選択肢のなかから，地域住民との交流が図れ るとなると, 従来とは異なる視点で, 屋久島の 地域特性を知ることになろう。少なくとも，そ れらを観光に活かしていくことが，屋久島にお ける今後の地域振興のあり方を探るうえで, 不 可欠な視点である。

\section{IV. 屋久島の新たな観光の潜在性 一滞在型エコ ッーリズムとはー}

\section{1. 聞き取り調査の概要}

筆者らは，2002年10月、2003年 2 月の二回に わたって，原地区およびその周辺の踏査にあたっ た。その際, 原地区の地域住民に対して, イン タビュー調査をおこなった。対象者は, 地区内 住民と設定した。具体的には町立神山小学校児 童や, 原地区で生まれ現在まで生活の拠点を移 していない70歳代と40歳代の男性が応じてくだ さった。インタビュー内容は, 非統制的な自由 インタビューとしたが，対象者本人の「自分史」 的内容と, 客観的事実として話に登場した原地 区の魅力との二点を大別して, 潜在しているエ コッーリズム可能性のある素材把握にあたった。

\section{2. 屋久町原地区における観光可能性 (1) 原地区の概観}

本地区は, 屋久町の中心地である安房地区と 平内地区のほぼ中間に位置する。人口は、ここ約 10 年は 400 人台半ばで推移している。基幹産業 の農業ではポンカンなどの相樀類や馬鈴薯を主 要産目とする。屋久島の他地区と同様に, 集落
の背後に急峻な山岳地形が迫っている。

(2) 原地区の「地域資産」一聞き取り調查から 原地区には益救神社や名水百選 ${ }^{17}$ の湧水など, 人文・自然にわたる独自の地域資産が存在する。 地区の背後にはモッチョム岳や千尋の滝といっ た，すでに観光名所として知名度の高い自然環 境がある。

原地区の中心に位置する益救神社は，ヒコホ ホデミノミコトを祭神とし，大隅五社の一つに 数えられている。旧暦 6 月 15 日におこなわれる 祇園大祭は，戦前より約80年間途絶えていたが， 近年復活の機運が高まり、有志によって実施に こぎつけた。地域行事が見直され，神社のもつ 杜の空間にふたたび人々の目が向けられるよう になったのである。また，この他にも，益救神 社には, 鯛釣りの神話, 遣唐使で有名な吉備真 備の漂着、江戸前期の儒学者 - 泊 如竹の書と伝 わる寄進碑などの歴史的地域資産に富んでいる。 これらの文化·歴史的資産のほかには，人々の 生活の基幹産業である農業経営への高い関心と 意欲が，地域住民に連綿と継承されていること も特筆される。たとえば，茶栽培の導入は鹿児 島県内でも比較的早く, 米軍による奄美 - 沖縄 占領期には，さとうきび栽培を活発に推しすす

17) 環境庁が1985年 3 月に全国百か所を選定した。調 査対象は、(1)きれいな水で、古くから生活形態、 水利用等において水質保全のための社会的配慮が 払われているもの、(2)湧水等で、ある程度の水量 を有する良質なものであり、地方公共団体等にお いてその保全に力を入れているもの、(3)いわゆる 「名水」として故事来歴を有するもの、(4)その他特 に自然性が豊かであるが、希少性、特異性等を有 するなど優良な水環境として後世に残したいもの、 とされた。また、選定のための判定条件は(1)水質 · 水量、周辺環境 (景観)、親水性の観点からみて、 保全状況が良好なこと、(2)地域住民等による保全 活動があること、を必須条件とし、このほか(3)規 模、(4)故事来歴、(5)希少性、特異性、著名度等を 勘案することとした。全国784件の推薦対象から、 「屋久島宮之浦岳湧水」が選定された。 
めた。最盛期には, ドラム午 1 本の出荷額が当 時の金額で 1 万円 ${ }^{18}$ 前後の高值をつけた。しか し，奄美の本土復帰とともにさとうきび栽培は 衰退した。 $4 ， 5$ 年前までは，柑橘類ブームが あったものの, 現在では下降気味となり, 農業 経営者の後継者不足と高齢化の進展は, 他地区 と同様に深刻化しているという。それでも，農 家の生産作物の中心に位置することに変わりは ない。それらをとおして，観光関連の価值を有 している地域資産は，表4のように整理できる。 では，どのようにしたら，このような地域資産 を活かした観光形態が確立しうるだろうか。一 つには，観光客に地域資産に関する情報を提供 することで，現状よりも多くの観光客の来訪が 予測される点に検討を加える必要がある。そし てもう一つ重要なこととして，そうした観光客 と地域住民が，経済的側面もふくめた繋がりを 増やせるかという点である。

\section{3.「はるお散歩マップ」の提案}

屋久島の場合，特定地域（本稿では原地区） に滞在して観光を楽しむには，基本的には徒歩 で移動することが望ましい19。自動車を利用す ると，3 時間もあれば島を一周できる。もちろ

\footnotetext{
18) 戦後直後は、極度のインフレが生じているために、 厳密な比較は困難だが、東洋鋳造貨幣研究所(1992 年開設の民間の博物館相当施設) は、『日本20世紀 館』(五十嵐 仁ほか編、小学館、1997年)に掲載さ れている物価の推移表の米価をもとに、1996年の 米価を基準として貨幣価值を算出している。それ によると、1946年の 1 円は現在の約267.23円に相 当することから、当時の 1 万円 $=$ 現在の約 267.2 万 円の価值をもっていたことになる。

19)集落内は、狭险な路地が多いことから、自動車に よる移動は非効率的である。また、滞在型のよう な、時間に余裕のある行程の場合、徒歩による視 点は、車空内からのそれとは受容する印象が異な るため、徒歩による集落内散策が、地域資産の発 見に繋がるものとして不可欠である(深見，2003)。
}

ん，何の施策もなしに，観光客が徒歩観光に転 化していくとは考えにくい。観光客に徒歩で観 光したいと思わせる仕掛けを提案し実践するこ とで，はじめて，観光客を地域への滞在型の方 向へと誘導することが可能となる。表 4 にある， これらの仕掛けや工夫のコンテンツを地図上に しめしたものが，図 3 の「はるお散歩マップ」 である。同様の地図は，全国各地に観光地で備 えられるようになっているが，原地区でもまた 同様のものを作成することが有用であろう。こ れまで屋久島においては，全島をカバーするよ うな絵地図は複数頒布されている。しかし，特 定の集落地域を対象として，しかも徒歩を前提 としているものは，これまで見あたらない。地 図には，原地区を構成する主要な道路や商店， そして本稿で提示した観光資源となりうる地域 資産がプロットされている。また，補足説明と して，それぞれの地区や路地の特徵等を記入し， 随時更新していく。この地図は，ある一定の時 期で完了するものではなく，今後，地域住民の 協力を得て，より詳細な地図づくり事業への起 点と位置づける。また, 観光の目的別に使用で きるよう複数の種類の地図を作成したりするな ど，様々な応用が考えられる。地域住民ととも に改訂し，新版を作り出していくことで，地域 住民にとっては，自地域をとらえなおす絶好の 機会となる。さらに，自分たちで作ったものを 観光客が利用することによって，観光客と地域 住民が，原地区の地域資産を媒介とした，サー ビスを利用するインセンティブも高まることが 期待できる。

その際の一手法として, 近年, 地域通貨を用 いた地域振興への取り組みがさかんになりつつ ある。地域通貨は，実際の金銭の授受が難しい と考えられるサービスの対価として，ある地域 
や団体で作った私的な「通貨」として流通させ るものである。循環型社会システムの一形態と して，地域コミュニティづくりの役割を果たす ものとして期待されている地域通貨の導入およ び活用には，急速な関心が集まっている (河合・
島崎，2003)。地域通貨は, 環境保全や, まち づくり活動をおこなう N P Oなどで, とくに地 域振興の一手法として, かつ環境教育的意義も 高いものとして，導入が図られる場合が多い。

表4. 原地区を中心とした地域資産

\begin{tabular}{|c|c|c|}
\hline 設定ゾーン名 & 地域資産名 & 概 \\
\hline 河口と港の観察ゾーン & $\begin{array}{l}\text { 鯛ノ川の神話伝説 } \\
\text { 岩石海岸 }\end{array}$ & $\begin{array}{l}\text { 屋久島に伝わる神話の舞台。 } \\
\text { 屋入島を形成する多種の岩石や地形的な変化が特徵的。 }\end{array}$ \\
\hline 親水ゾーン & $\begin{array}{l}\text { 山河湧水 } \\
\text { 山河公園 }\end{array}$ & $\begin{array}{l}\text { 「名水百選」の湧水。 } \\
\text { ベンチや植樹のなかを湧水が流れていく親水公園。 }\end{array}$ \\
\hline 文教交流ゾーン & $\begin{array}{l}\text { 神山小学校 } \\
\text { 原公民館 }\end{array}$ & $\begin{array}{l}\text { 「総合的な学習の時間 } 」 \text { 等の活用による交流。 } \\
\text { ワークショップ講座などの開催、地域住民との集団交流。 }\end{array}$ \\
\hline 農業体験と対話の交流ゾーン & $\begin{array}{l}\text { 農家, 商店, 路地の由来 } \\
\text { 果樹園 }\end{array}$ & $\begin{array}{l}\text { 農業体験や地域通貨利用による地域住民との対面交流。 } \\
\text { 屋久島の農業を象徵する景観群。 }\end{array}$ \\
\hline クラフトふれ合いヅーン & クラフト工房 & 地元素材を利用した陶芸、染物体験。 \\
\hline 屋久島の今とむかしの思索ゾーン & $\begin{array}{l}\text { 森林群 } \\
\text { 巨石群 } \\
\text { 千尋の滝 }\end{array}$ & $\begin{array}{l}\text { 登山よりやさしい森林浴の場。 } \\
\text { 屋久島の大部分を形成している花崗岩の転石。名前がついている } \\
\text { ものもあり、巨岩信仰の名残を体感。 } \\
\text { 屋久島を代表する自然景観。 }\end{array}$ \\
\hline
\end{tabular}

注:現地踏査および地域住民への聞き取りにより作成。

ヘモッチョム岳

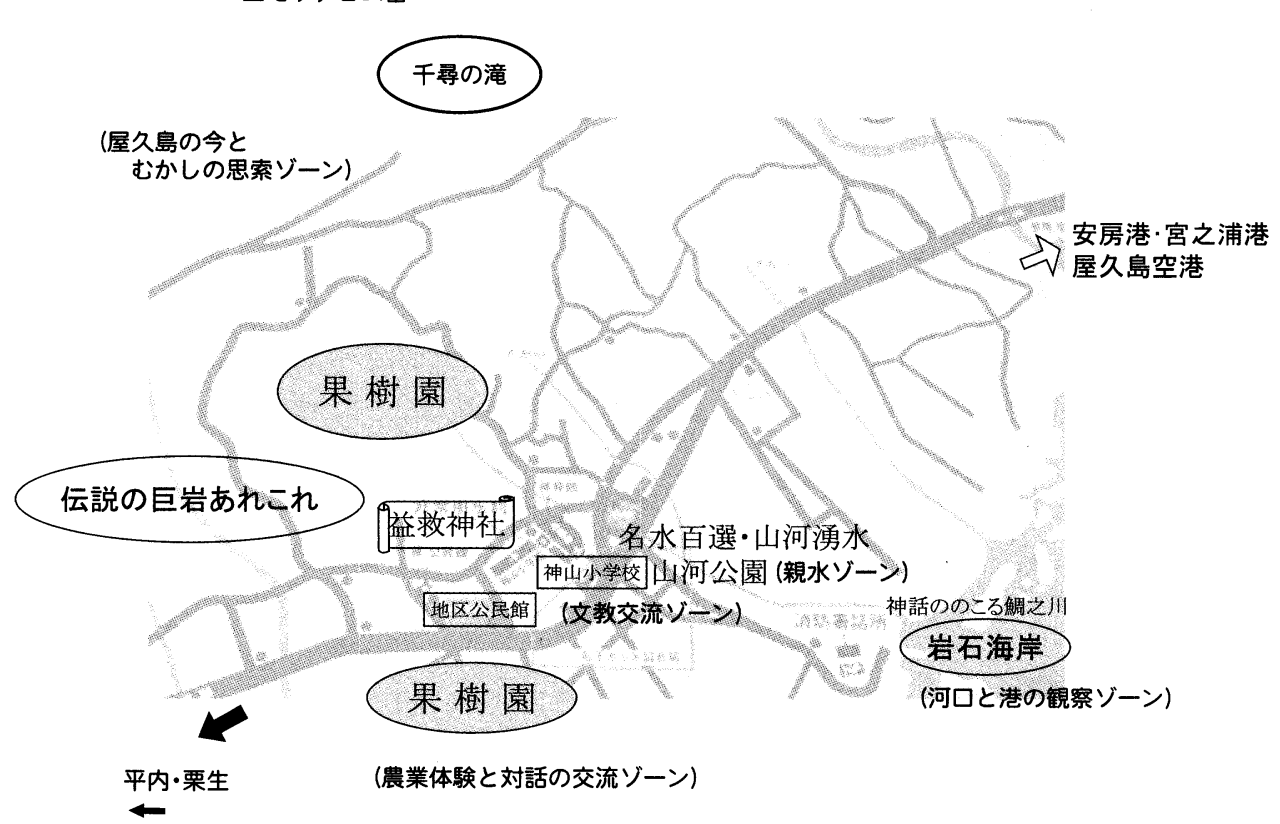

(クラフトふれ合いゾーン)

図 3．原地区の地域資産を紹介した「はるお散歩マップ」

注:踏查結果をもとに筆者ら作成。本図の道路網原図は、原地区公民館内掲示の防災地図看板をデジタル撮 影·処理して使用。実際の地形図とは縮尺にずれがあるため、本図でも正確な縮尺表記は省略した。およそ

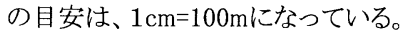


その前提にたって, 本稿では, 地域通貨を, 観光客と地域住民のコミュニケーションを促進 するツールとして導入する試論を提案する。筆 者らは，2002年 5 月に屋久島において地域通貨 ワークショップを開催した ${ }^{20}$ 。このときの経験 からでは，「わざわざこんなものを使わなくて も, 日ごろからサービスのやりとりは無料で活 発におこなわれている」との指摘があった。こ のような地域での, 地域通貨の利用は, サービ スの交換に「他人行儀」さを生むこととなって しまう。すなわち, 屋久島のように伝統的なコ ミュニティが強固な地域については, 地域住民 どうしをつなげる働きをする地域通貨は, 期待 されるそれとはむしろ逆効果の作用をもたらす 恐れがある。地域通貨とはそもそも, 適度な距 離を置いた人間関係の新たな構築をもたらすも のと考えられる (農林中金総合研究所編, 2002 )。そうすると，屋久島のような地域において は，密接な人間関係と若干距離を置いたものに し，住民どうしの関係を疎遠にしてしまう可能 性があるためである。

一方，地域住民と観光客との間で地域通貨を 利用するならば，両者がコミュニケーションを 開始する契機となり, 交流が生まれることが期 待できる。このような仮説のもと, 今後筆者ら は，屋久島において実際に地域通貨の導入を予 定している。

\section{4.「地域資産」を活かした原地区観光一地域} 通貨をキーワードに

20)「地域発展を目指した新しい地域通貨システムの 提案」と題して、2003年 5 月に環境自治体会議屋 久島会議（開催地：上屋久町、屋久町）でも同様 の報告がなされた。
（1）人的資産と自然的資産をむすぶ地域通貨

具体的には, 原地区における滞在型ツーリズ ムと地域通貨を組み合わせて導入することにな るが,この効果として以下のものが挙げられる。

原地区で導入される地域通貨は，おもに観光 客と地域住民のコミュニケーションを活発にす ることを目的とする。観光客と住民の間には， 観光客が帰った後にも継続的な関係が生まれる ことが望ましいが，再び地域を訪れるという保 証はない。そこで，原地区で導入を検討するシ ステム（以後, 本稿では「原方式」とよぶ；眓 4 参照）では，観光客については，口座の負債 を認めない方向で導入を検討したい。ただし， 観光客と原地区には，事前の接点が存在するケー スは稀なため，原地区を訪問する観光客が事前 に原方式のクレジットを保有している可能性は ほとんどない。そこで，原方式では，原地区を 訪れる観光客が，「はるお散歩マップ」と，一 定額の地域通貨を購入する必要がある。なお, 一旦購入した通貨は, クーポン券のようなもの であるため，再び円 (実際の金銭) に換金する 、ことはできないものとする。

観光客は原地区で宿泊や食事をする際，ある いは前節で述べたような地域住民からのサービ スを受ける際に，地域通貨を使用することがで きる。観光客が換金できないクレジットを持つ

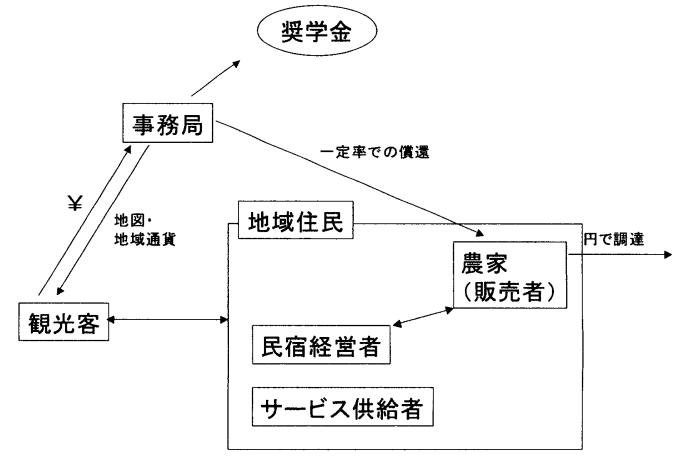


ことは，観光客が地域内で一定額以上の消費を おこなうことを意味する。その消費対象として， 地域住民とのコミュニケーションを要求するも のを多く提供することで，住民とのコミュニケー ションが大幅に促進されよう。また, 観光客の 需要に応えるためには, 地域住民みずからが供 給をおこなわなければならないため, 彼らにとっ ては，一定の雇用効果を創出することになる。

宿泊施設などでは, 円と地域通貨の併用も可 能にする。そして, 地域通貨を受け取った地域 住民は, 基本的にこの地域通貨を地域内での財 やサービスの購入に充てることとなる。とくに， 宿泊施設や飲食店では食材を地域の農家から調 達する際に用いれば, 食材の地産地消が促進さ れ，農業経営者の収入増にもつながる。さらに， 食材への需要は, 通常多岐にわたるため, 生産 作物の多様化が図られ, 年間を通じた農業経営 者の収入を一定規模確保する役割も期待できる。 ただし，地域に食材を供給する農家では，食 材となる作物を生産するために, 肥料や種苗な どを原地区外から購入する必要がある。この点 については, 可能な限り地域内で発生する有機 系廃棄物を肥料として再利用し, 在来種の種苗 を自家繁殖するなどの対応をおこなうことで， より食材に安心感という価值が付加されるとと もに, 自地区内での自給度を強めることが可能 となる。また，それでも必要となる財の移入の ための費用については, 観光客が地域通貨と交 換した円を利用する。農家は，原方式の通貨を 一定割合の割引の後，円と交換することができ， 食材の生産に必要な原料の購入に充てられる。

ここまで, 観光客が地域通貨と交換した円の 使途について, 農家が償還する地域通貨との交 換だけを提示してきたが，当然ながら，事務局 の運営経費にも転用できる。しかし，それでも
償還の際の割引率と運営経費によっては, 円資 金の余剩が生まれることが考えられる。これに ついては，原方式を，いわゆる第 3 世代の地域 通貨 (坂田, 2003b) として, 奨学金として活 用する方法が考えられる。原地区で奨学金シス テムを導入することで，原地区出身の青少年が 島外に出て就学する際に必要な資金を, 地区全 体で賄おうというシステムである。このことが, 地域住民に教育費の過重な負担を軽減する効果 をもたらす ${ }^{21}$

（2）地域通貨活用による新たな観光効果

ところで，地域で取引がおこなわれるサービ スとは何であろうか。そもそも，前節で述べた システムが活発に運営されるようになるために は，地域から供給されるサービスが魅力的なも のでなければならない。すなわち, 地域通貨の 導入により，自動的に地域が活性化するのでは なく，地域住民が主体となって魅力的なサービ スを創出する必要がある。

原地区において提供できうるサービスは，さ まざまなものが考えられるが，基本的には，(1) 農業体験，(2)古老(地域住民のうちの高龄者)に よる昔ばなし, (3)クラフト体験などの体験学習 の三つが中心となろう。このなかから，地域資 産との関連や地域住民に受容されていて，かつ 魅力的なサービスを精選し，活用策を練ってい くことで，原地区の住民がそれぞれ顧客を獲得 することが期待される。

地域住民が主体的にサービスを供給すること

21) 原地区での奨学金提供については地域通貨にどの 程度の人数が参加するかが鍵となる。仮に年間 2,0 00人が原地区を訪れ、それぞれ3,000円の通貨を購 入するものとすると、原方式の収入は 600 万円にな る。このうち、 3 割程度が奨学金として用いられ ると考えると、年間 180 万円程度の資金を提供する ことができる。 
には，副次的な効果もある。それは，住民がそ れぞれの地域の特性を発見する過程で, 個々の アイデンティティが確立されていく点と, 地域 にこれまで眠っていた人的・物的資源の発掘が できる点である。これらの資源は, 地域活性化 のポテンシャルを高めるものであり, 有効に活 用されれば，地域の有する潜在能力を前面に打 ちだした，新しい地域振興の手法となろう。

また, 人材育成や能力開発に地域一体で取り 組むことによって, 近来, 継承されずに消滅が 危惧されるような民俗文化, 生業の知恵が継承 される可能性が高まり, 地域通貨の導入による 活性化効果が持続的に伸展していくと予測でき る。

\section{V．おわりにー屋久島からみたエコッーリズム の展望}

全国的に急激に進展している「平成の大合併」 は, 条件不利地域に対して従来型の手厚い財政 援助を継続することは困難であるという，国の 意思表明への対応策といえる。条件不利の要因 が累積している島嶼部は, 市町村合併に対する 対処と同時に，地域の生き残りをかけた振興策 の模索を続けている。

この際，グローバリズムに対抗できるほどの 経済資源をもたない，大部分の島嶼に与えられ る選択肢は，必然的に限られてくる。したがっ て, 多くの地域が, 観光, とくに滞在型エコッー リズムを主要な地域振興策の一つに掲げる。た しかに, 今日の島嶼は, 手つかずの自然や, 引 き継がれてきた歴史・文化的資産など，エコツー リズムを成立させる潜在的な要件を保持してい る。しかしながら，屋久島のように，観光客が 複数回訪れることが多いケースであっても, 地
元の地域住民が主体となったエコツーリズムは， 実現していない。島嶼をめぐるエコッーリズム 確立の条件を把握するには，実践にあたるなか から析出し, 試行錯誤であっても, 可能な限り 早期に，モデル事業として実現にあたることが 求めている。

本稿は, 地域住民の生業と連関した, 滞在型 エコツーリズムに焦点をあて，議論してきた。 原地区の特性を考えた場合, 農業体験や, 学校 や公民館という学校・社会教育施設との連携に よる交流に, 新たな観光需要を見込める。都市 部で生活する人々にとって, 屋久島の自然環境 は斬新に映る。屋久島の人々にとって当たり前 の自然が，都市部の生活者には予期していた以 上の満足感を付与することを, 世界自然遺産登 録地は実証している。今日の社会的要請は, こ こからさらに一歩踏み込み, 屋久島の人々にとっ てありふれた「日常」としてとらえている身近 な生活環境, たとえば相橘類の収穫や土づくり 等の農業体験, あるいは小学校や公民館といっ た文教施設での交流事業を観光資源として発信 することが求められる段階にきているのではな いだろうか。事実，このような実践は，すでに 子どもを対象とした，「総合的な学習の時間」 などでの環境教育の一環として実施されてきて いる。また，子どものほか, 引率にあたる大人 にとっても, 同様の事業は忘れ難い思い出とし て残るであろう。同時に, 地域住民から考えだ された観光プログラムがあれば，それは協働形 式の失導的モデルケースとして, 新しい屋久島 観光の確立にむけて, より有用に貢献するもの と期待できよう。

そのうえで, 地域資産の活用例として農業体 験をとりあげてきた。現在，人手不足の農家は， それを補うために臨時雇用者に対価を支払って 
いる。原方式では, 農業体験をしてみたい観光 者と, 人手の欲しい地域住民という, 双方のニー ズが合致する点に着目した。その結果，一定期 間，農業体験をふくめた滞在型ツーリズムの確 立可能性は，充分に存在するといえる。

本研究における中心的な考察の一つは, 実践 的な事業を試みる際に有用と思われる，いくつ かの仕掛けや工夫の提示にあった。これらに対 する検討をとおして，地域住民と観光者の双方 を結びつけるうえでの，具体的な課題も明らか になった。具体的に列記すると，事業成立の前 提として，マスッーリズム的な人員移動ではな く, 少人数単位の受け入れ体制の整備, 繁農期 や閑農期など，地区の受け入れ可能な体験業務 に関する情報の把握を早急に進める必要がある 点だ。また，滞在型とするには，周辺地区をも 視野に入れ，観光地となりうる資産を，線ある いは面で結ぶための導線整備 (図 3 をもとにし た散歩専用の地図や手づくり製の簡易案内板な どの設置) も検討を要する。

屋久島における，滞在型エコツーリズムの確 立にあたって諸種の課題はあるものの，新しい 観光需要に応えることが可能で, かつ地域資産 の活用，人間環境を観光の舞台の中心とする事 業に可能性が見出される点が明らかになった。 このような発想は, 屋久島観光においては，ど ちらかというと新しいものではある。しかし， エコッーリズムが日本でも徐々に浸透しつつあ る現在，むしろ自然環境との共生を考えながら 観光をするには，屋久島は自然環境への認知度 が高いだけに，長期滞在型の新たな観光に対す る潜在的需要も高いと位置づけられる。

島嶼の振興策という視点に立ち返ってみれば, このような可能性は，原地区に限って存在する ものではない。他地区でも，地域資産をいかに
導線で結び提供できるのか，地域特性を把握し， 発信していくことで，地域資産の活用と長期滞 在を指向するといった，観光需要の質的向上も 必然的にすすむといえる。

\section{謝 辞}

本稿は，文部科学省科学技術振興調整費「先導的研究 等の推進」『循環型社会システムの屋久島モデルの構築』 〔代表：鈴木基之 (国際連合大学)，2001年度～2003年度〕 の助成を受けた。

本稿の執筆にあたっては，屋久町原地区の皆様，とく に聞き取り調查および果樹園や巨岩の案内に貴重な時間 を割いてくださった日高照夫氏にお世話になった。また， 鹿児島大学大学院人文社会科学研究科教授の皆村武一先 生・山田誠先生には, 観光と地域振興について有益なご 教示を賜った。これらの方々に深く感謝する次第である。

\section{文 献}

大山勇作 (2003)：「屋久島に扔けるエコッアー の経緯 と現状」.『第11回環境自治体会議屋久 島会議資料集」. pp.90-91.

翁長秀正 (2000) : 国内のエコッーリズムの現 状と課題. 『沖縄型エコッーリズムの試み』。沖縄地域問題研究会 編, pp.75-108.

河合正弘・島崎麻子 (2003)：日本の地域通貨 制度一現 状と課題一. 社会科学研究, 54-1, pp.145-170.

坂田裕輔 (2003a)：「屋久島に打ける経済循環 - 活性 化システムの分析と提案」。屋久島にゼ ロエミッショ ン社会を創る』，鹿児島大学，pp.26-33.

坂田裕輔 (2003b)：「持続可能な地域開発を支 援する ための地域通貨システムのデザイン」. ワールドワイ ドビジネスレビュー・同志社大 学ワールドワイドビジ 
ネス研究センター, 4 (3), pp. 161-177.

柴崎茂光・永田 信 (2000)：「屋久島の利用 価值の評 価」『世界遺産の経済学一屋久島の 環境価値とその評 価』. 栗山浩一 - 北畠能房 - 大島康行編著, 勁草書房, pp.65-103.

田島康弘 (2001)：屋久島における「新住民」の来住. 鹿児島大学教育学部紀要 (人文・社 会科学編), $52, p p$. 41-59.

中井達郎 (2002)：地域にとってのエコッーリ ズム. 地 理科学, 57-3, pp.33-39.

中田隆昭 (2003)：「生活域で行うエコッアー」. 『第11 回環境自治体会議屋久島会議資料集』. pp.92-93.

農林中金総合研究所編 (2002)：『共同で再生 する地域 と暮らし』. 日本経済評論社, $184 \mathrm{p}$.

深見 聡 (2003)：N P O 法人が地理教育に果 たす役割 と課題-N P O 法人「かごしま探検 の会」の実践事例 から-. 新地理, 51-1, pp.1- 18.

フンク・カロリン (2002) : エコッーリズムは 持続可能 なのか. 地理科学, 57-3, pp.4-13.

フンク・カロリン\&淺野利久 (2002)：エコッー リズム の概念と課題. 地理, 47-3, pp.22-27.

宮内久光 (2003)：沖縄県におけるエコッーリ ズムに関 する基礎的研究. 琉球大学法文学部 人間科学紀要 (人 間科学), 11, pp.83-121.

村上光信 $(2000)$ : 屋久島観光におけるアイラ ンドテラ ピー概念の一考察. 島嶼研究, 創刊 号, pp.109-119. 山田 勇 (2002)：エコッーリズムと生態資源. 科学, 72-7, pp.690-695.

山村順次 (1995)：『新観光地理学』. 大明堂, $270 \mathrm{p}$. 吉田春生 (2003)：「屋久島観光の現在」.『エ コッーリ ズムとマスッーリズムー現代観光の 実像と課題』. 大 明堂, pp.163-187. 